\title{
Rethinking Mass Communications in Norway
}

\author{
The Neglected Power of the Centre-Left Alliance \\ in the Early $20^{\text {th }}$ Century and its Importance until the Present
}

\author{
Henrik G. Bastiansen
}

\begin{abstract}
The present article discusses the importance of the early years of mass communications in order to understand the shaping of them - the power of creating mass media for whole nations. It begins with references to scholars studying large nations and asks whether their results can be generalized to smaller countries. Therefore, it uses Norway as a case study. To what degree were Norway's four major mass media - press, film, radio and television formed institutionally in their early years? And if they were formed in this way, how long did the consequences of such a formation last? These questions have been neglected topics in research, so in order to answer them we also need to rethink the connections between the different media.
\end{abstract}

Keywords: formative years of mass communications, media power, media system, media history

\section{Introduction}

The person who wants to see his/her own time correctly, must see it from afar. José Ortega y Gasset, in The Revolt of the Masses, 1934: 51

In countries like the United States and Great Britain, we know that the modern means of mass communication became organized quite early. A large body of scholarly work has shown the importance of the formative years: What happened then established the foundations for much of the later development. Pioneers started up new media, organized their power and achieved dominance over institutions that became world famous giants of mass communications. The forming of the American press and the Hollywood film industry, the Walt Disney Company or broadcasting institutions like NBC (1926), CBS (1927) and ABC (1943) are examples of this. ${ }^{1}$ We find a parallel case in the forming of the British press and an institution like the BBC (1922). ${ }^{2}$

But if this pattern of early importance is true for big countries, we have to ask whether it can be generalized. Do we find it in other Western countries? Will we also find it in small countries? Will we for instance find it in small countries located in the northern periphery of Europe - like Norway? If we do not, we cannot generalize. But if we do, 
we may have reached a deeper understanding of the importance of the formative years of mass communications and how early power can achieve lasting consequences: forming the dominant media of a nation.

Let us therefore use Norway as a case study to address the following research question: To what degree were the four major mass media - the press, film, radio and television - formed institutionally in their early years? And if they were formed in this way, how long did the consequences of such a formation last? This has been a neglected topic in research, so in order to answer these questions we need to rethink the connections between different media. In the text that follows, I will discuss this topic in some detail, and the events in their chronologic order. But before discussing the organizing of the media in the early $20^{\text {th }}$ century, let us start with the historical context.

\section{The Beginning: From the Art of Printing to Freedom of the Press ${ }^{3}$}

All European countries were marked by a close relationship between the Gutenberg art of printing, censorship and the ideal of press freedom. ${ }^{4}$ This was also true of Norway, which was a Danish dependency during the period 1380-1814, governed by DanishNorwegian kings located in Copenhagen. Thus the art of printing came to Norway by way of Denmark. The first Norwegian printing presses were started up by Danish printers who established their operations in the country around $1650-200$ years after Gutenberg. By that time they had been operating in Denmark since the end of the $15^{\text {th }}$ century. They also shared censorship regulations, which had been introduced in both countries as part of the Reformation in 1536. From that time on, all texts that were to be printed had to receive advance approval (called "imprimatur") from a government censor. This function was usually performed by professors of theology from the University of Copenhagen. The Kingdom of Denmark-Norway practised censorship until 1770. In that year, the idea of print freedom received its Danish-Norwegian breakthrough. This was announced through a decree dated the $14^{\text {th }}$ of September 1770, issued by the King's personal physician, Johann F. Struensee (1737-72). He had for all practical purposes assumed the powers of government, since the King was diagnosed as mentally deranged. Struensee wished to be a reformer, and the introduction of print freedom was his first reform. The reactions were immediate: Printers began to publish all kinds of expressions of opinion. Debate and criticism flourished, as an arena of public discussion emerged - 20 years before the French revolution in 1789.

The first Norwegian newspaper - Norske Intelligenz-Seddeler - started up in 1763. In 1767 it was joined by Adresseavisen in Trondheim. The public opinions that emerged in publications like these were gradually regarded as a kind of law court, the purpose of which was to investigate the actions of the government, but the prerequisite for such a function was the existence of print freedom. It had to be possible to criticize the King and the government without risking the loss of your head. Although these were bold ideas, they were nonetheless accepted and adopted in Denmark-Norway towards the end of the $18^{\text {th }}$ century.

Young Norwegian students picked up on such new developments when they were studying in Copenhagen in the 1790s. Many of them congregated in The Norwegian Society, a club for literature and debate between 1772 and 1813..$^{5}$ In 1814, many of these students had become government officials or civil servants, who were sent to Eidsvoll to create a constitution. In that document they formulated a $\S 100$, which declared that 
"Press Freedom should take Place." This meant that the Constitution banned the use of state censorship. In addition, the Constitution stated that the expression of "frank opinions" about the government and its operations was "allowed for everyone". This is what we today call freedom of expression.

In this way, a number of the most radical ideas of those days found their way into the Norwegian Constitution of 1814. It therefore represents an important watershed in the media history of the country. The Constitution changed the status of the inhabitants of Norway from being subjects of the King to being free citizens with their own rights. Among those rights were print freedom and freedom of expression. From that time on, Norwegians could criticize the King and the government publicly without risking their lives. This became important because in 1814 Norway was forced to join Sweden in a new Scandinavian two-state union ruled by the Swedish King in Stockholm. This union lasted until Norway achieved national independence in 1905. During the decades after 1814, an oppositional press therefore emerged in Norway, and it expressed its criticism of the government and its policies. Newspapers like Morgenbladet and Statsborgeren, etc., belonged to this category. In this way, the art of printing, censorship and print freedom also constituted the starting points of Norwegian media history.

\section{The Continuation: The Media Become Mass Media ${ }^{6}$}

Around 1850 the Industrial Revolution reached Norway. Large factory buildings were built along the rivers. People began to move from the countryside to the cities, where many of them became factory workers. In the course of a very short period of time, Norway experienced a transition from an agricultural to an industrial society. A money economy soon replaced the old barter system.

Industrialization also influenced the media. The first great change came with the railway, as the first Norwegian train line was established between Oslo and Eidsvoll in 1854. ${ }^{7}$ When people discovered the great economic progress that followed in its wake, everyone wanted their own railway. A great many new lines were built, so that in 1875 there existed as many as 970 miles of railway in Norway. The rails bound stations and regions together. The carriages were full of people, who would while away their time by reading newspapers, magazines and books. Along the railway tracks, telegraph lines were constructed, enabling people to send messages. The telegraph, which utilized the Morse code, is the first example we know of modern telecommunications. This operation was carried out by the Telegraph Authority, a state monopoly that was founded in 1855 . And then in 1880, the telephone reached Norway. It was the International Bell Telephone Company that introduced the new service - only four years after Alexander Graham Bell's famous invention in 1876. Private telephone companies strung their wires from pole to pole and established themselves in towns and other built-up areas. The telephone made everyday life much simpler, and therefore it soon became very popular in Norway. In 1879 followed the Edison phonograph - demonstrated in Oslo for the first time - as a device that could record, store and reproduce sound. It laid the foundations for the later gramophone and thus for the modern music industry. The photograph, which could capture, store and reproduce light, represented a parallel development. In Norway, the breakthrough for photography came in the 1860 s. Now professional photographers travelled around on trains and steamships to try to capture the Norwegian landscape - often 
used as advertisements directed at potential tourists. A number of classic Norwegian motifs were created this way.

In the $1890 \mathrm{~s}$, in cities like Berlin and Paris, people began to show photographs mounted in series, creating the illusion that the subject was actually moving. Thus the moving image - the cinema - was born. On the $6^{\text {th }}$ of April 1896, the first public showing of film took place in Norway - only a few months after the famous Lumière premiere in Paris. The venue for this event was the popular Circus Variety in Oslo. The moving photographs were a sensation, and a fascinated public flocked to see the new phenomenon. The first permanent Norwegian movie theatre opened its doors in 1904, to be followed shortly thereafter by many more. Already before 1910 these new attractions had created a veritable migration of curious viewers.

Film soon became a medium of such magnitude that it could only be compared to the press. Norwegian newspapers had recently changed their mode of operations from manual production and modest circulation numbers to more advanced and efficient production on the modern rotary press. They were now able to churn out large circulation numbers. Prices dropped while the readership increased. In this way, the press was transformed from a craftsman's product to an industry that made its living from the dissemination of news and opinions. New papers like Aftenposten (1860), Bergens Tidende (1868) and Dagbladet (1869) were started. Press workers gradually began to view themselves as a fourth branch of government, showing the growing importance of the press. New printing techniques could now be utilized in mass production. This transformed the newspapers into mass media and the process into mass communications. Now they reached a new audience, composed of millions: voting for all males in Norway was introduced in 1898 and female voting in 1913 - both by the Liberal party. This expansion of voting practice to every adult member of society changed the Norwegian democracy into a mass democracy. This also increased the importance of methods of influencing public opinion. So, let us now turn to the three main examples of organizing the modern media in Norway in the early part of the $20^{\text {th }}$ century.

\section{The Party Press: An Organized Mass Influence}

The first example of early organizing of the media is the party press. Around and after 1900, newspapers were available everywhere for the masses: in the streets, in the cafés and at the railway stations. And people were avid readers. The Postal Service's circulation of newspapers grew rapidly: In 1876, it distributed 5.86 million newspapers, a number that had grown to 14 million by 1892. In Oslo in 1890, 120 newspapers and magazines were distributed to subscribers. When the Narvesen kiosks were started up in 1894, they sold 400,000 newspapers. By 1898, they were selling approximately 3.3 million newspapers. In 1901, Narvesen owned 37 kiosks. At that time they sold two million newspapers annually. In 1918, the number of kiosks had increased to 223, and they had increased their offerings from 230 newspapers and 420 weekly magazines in 1910 to more than 900 publications in 1920 . The number of newspapers sent by mail grew from 112 million in 1913 to 187 million in 1919. By 1925, the Narvesen kiosks were sending out a grand total of 33 million newspapers annually, an enormous increase since $1894 .{ }^{8}$ The people had grown "more and more demanding in their desire to be kept up to date", wrote the newspaper Tidens Tegn. ${ }^{9}$ 
These numbers reveal some of the dimensions of the Norwegian press as a mass medium. The newspapers were an industry of news and opinions that truly reached the masses. A newspaper was often read by several people; therefore the actual importance of a paper could be much greater than the circulation numbers alone indicated. The significance of the newspapers as a mass medium was particularly visible in the party press.

The party press in Norway developed between 1880 and 1920. This was a period of great growth for the newspapers business. It was the intense struggle over the principle of parliamentarianism in the 1880 s that made the newspapers declare their allegiance to the political parties. The Liberal Party (Venstre), Norway's first political party, was founded in 1884. The Conservative Party (Høyre) was founded later the same year. Those two were enemies from the word go: The Liberals fought for parliamentarianism, while the Conservatives were opposed. This struggle led to the establishment of a separate party press for each of the two parties. The papers representing the Left were radical and liberal and tended to attract relatively recently founded newspapers like Dagbladet and Verdens Gang in Oslo, along with a number of local and regional papers like Foedrelandsvennen and Bergens Tidende. The older papers, however, espoused more conservative views and therefore supported the Conservatives. Morgenbladet and Aftenposten were the most important Right-leaning papers in the capital, while papers like Adresseavisen, Morgenavisen and Drammens Tidende presented the political agenda of the Conservatives in other parts of the country.

In the beginning, the newspapers on the Left and Right were the two dominant groups in the party press, but as early as 1884 the newspaper Vort Arbeide (Our Work) was started. This was the country's first permanent working-class paper. Vort Arbeide was the main newspaper for the Norwegian Labour Party, which, interestingly enough, was not founded until 1887, three years after the newspaper. The paper soon changed its name to Social-Demokraten. In 1923 it was re-named Arbeiderbladet. It soon became the leading newspaper in the rapidly growing Labour press, which additionally consisted of papers like Bergens Arbeiderblad and Nordlys in Tromsø, among others.

The fourth newspaper group with an identification in party politics, the agrarian press, emerged around 1920. Its main newspaper was Nationen (The Nation), which was started up in 1918. Østlendingen, based in Elverum, became the second most important agrarian paper. A number of smaller newspapers also belonged to the agrarian press. It was a mouthpiece for the Farmers' Party, which was founded in 1920. This newspaper group was also closely connected to the Norwegian Farmers' Association. The agrarian press spoke up for the interests of the farmers, a cause that was sometimes referred to as "the gospel of the soil." These newspapers fought for the primary industries, i.e., agriculture, forestry and fisheries, and were opposed to the spread of urban influence in the rural areas of Norway.

In this way there evolved four large newspaper groups with an identity based on party politics between 1880 and 1920. Each one of them founded their own press association. They were given names like the Conservative Press Association, The Press Association of the Left, The Agrarian Press Association, The Norwegian Labour Press and the Norwegian Press of the Right. The Labour press pioneered the inauguration of the Social-Democratic Press Office in 1912; it later changed its name to the Workers' Press Office. As a counterweight, the Liberals, the Conservatives, and the Farmers' Party founded their own press offices. In their headquarters in Oslo, they produced the appropriate party-political materials for their own press groups. 
Between 1920 and 1940 the party press consolidated its position. This was a period of economic crisis, strikes and general unrest. The newspapers also had a hard time economically, but they were supported by their respective parties. The ties grew so close during these years that newspaper work and party politics became two sides of the same coin. The party press quite simply became the normal type of newspaper in Norway. There was no serious opposition to this development. The politicians wanted effective mouthpieces for their own policies. Journalists and editors willingly took on such a role, and the readers accepted it. This was decisive for the role of the press in Norway: the party newspapers became political and ideological weapons in the struggle for political power. They loyally produced propaganda for their own parties and attacked all the others. This double task was the most prominent feature of the party press.

This made the party press instrumental in augmenting the conflicts in society. While the Labour press agitated intensely for the Labour movement, the unions and the Norwegian Labour Party, the Conservative and Liberal press opposed these ideas with equal fervour. The papers' journalism became pointed and polemical, while they fought for the readers' souls, for people's convictions and public opinion. And they utilized just about every possible linguistic and typographical means at their disposal. Quite simply, the party press was actively engaged in spreading propaganda, in order to consciously influence their readers. That the newspapers were instruments of propaganda was something that journalists and politicians almost took for granted. They believed that there was a direct causal relationship between the size of a party's press and that party's actual election results. If a party started up a new party newspaper, it would consequently improve its position at the next election. This conviction motivated the party press to work hard for the cause and was the reason why the parties regarded their papers as their primary vehicles of agitation. But such a conviction at the same time created fear of the opposition's press. Therefore the party press soon became concerned about measuring its numerical strength. The Labour press - internally referred to as "an effective instrument of propaganda" - in 1920 consisted of 33 party papers and six magazines of the social-democratic persuasion, all in all 39 publications, not counting The Workers' Press Office. The Norwegian Labour Party included detailed numerical surveys of all the Labour papers in its annual reports. ${ }^{10}$

From the beginning in the 1880 s, the main line of conflict in the party press went between the Liberal and the Conservative press, but after a while the growth of the Labour press started to frighten the Liberals into a position not so far away from the Conservatives. This development was hastened by the Russian Revolution in 1917. From that time onwards, the main line of conflict began in earnest to go between the non-socialist and the socialist Labour press. In Oslo this conflict played itself out as a conflict between Arbeiderbladet, on the one hand, and non-socialist papers like Aftenposten, Dagbladet and Tidens Tegn, on the other.

The party press was the country's greatest industry of influence. It reached its readers every day, in numbers that could be counted in the millions annually. The Conservative press, for example, comprised 57 newspapers from 52 independent newspaper operations in 1937 - and called itself "the great national people's press". Gustav le Bon's book The Psychology of the Masses was familiar among its journalists. He was quoted as follows: "Words that are repeated over and over will finally be indelibly impressed on the obscure hiding places of the subconscious, where the motives for our actions 
are born". ${ }^{11}$ Repetitions would enhance the effect of the message, whether the aim was political or purely commercial. The party press did in fact not only deal in political influence, but was also responsible for engaging in economic influence through their advertising. Thus, the party press was actually much more commercially oriented than most people have believed in later years. The party press fought hard for the money available for advertising and other types of promotion, and they even established their own advertising offices to strengthen their positions in this struggle.

The party press was of course not an exclusively Norwegian phenomenon; many countries had this type of newspaper industry. What was special for Norway was the fact that the party papers were to such a great extent successful in developing a centralized influence that permeated local communities in an organized way. Party newspapers could be found at almost every place of publication all over the country. Each paper functioned as the local spearhead for its party and its own group of newspapers, by printing the materials sent out from the group's press office in Oslo. What particularly characterized the Norwegian party press, then, is the fact that very few local communities escaped its persistent agitation and constant attempts to influence people's opinions through explicit party propaganda. ${ }^{12}$

\section{Film and Cinema: The Norwegian Model}

The second example of early organizing is the film and cinema industry. While the party press was growing strong, masses of people were flocking to the new cinemas. In $1905,760,000$ people went to the movies in Norway. The increase during the next few years is almost unbelievable: 1.9 million visits in 1906, 3.8 million in 1907, 6.1 million in 1908, 7.8 million in 1909 and 10 million in 1910. A peak was reached during the 1920-21 season when 21.6 million people went to the movies. The attendance decreased somewhat in the 1920s, but started growing again in the 1930s, reaching 20.2 million in 1939. During the German Occupation, the numbers went up from 16.9 million in 1940 to 31.1 million in 1945. The all-time record for annual cinema attendance in Norway - 35 million visits - was reached in the years 1956-57. ${ }^{13}$

Numbers such as these clearly illustrate the dimensions of cinema as a mass medium. It is obvious that in Norway, too, films appealed to a large and varied audience. American crime and western movies were extremely popular, but gradually Norwegian films grew in popularity as well. In 1920, the feature Fante-Anne, directed by Rasmus Breistein, inaugurated a national breakthrough for Norwegian films. All of them were silent movies. The first Norwegian sound film was Den store barnedåpen (1931). Towards the end of the thirties, Norwegian "talkies" came to represent a regular Golden Age, with titles like To levende og en død (1937), Fant (1937) and many others. ${ }^{14}$ The leading Norwegian movie-maker during this period was Tancred Ibsen.

Behind these individual films, a unique Norwegian film world had developed. In other Western countries, the production, distribution and viewing of film was a privately owned and vertically integrated enterprise, so that the cinema earnings financed the production of new films. In Norway this did not happen, because of the Cinema Act of 1913, which introduced two regulations that were to have a long-lasting impact. The first of these was the stipulation that all movies had to pass through a public advance control. The law thus introduced censorship of films, an arrangement that was quite controversial 
at the time. The censorship provision was the end result of a moral offensive that had started around 1910. Teachers and the so-called "Decency Leagues" feared that children and young people could be influenced negatively by watching movies. The champions of censorship pointed to the cinemas' increasingly aggressive marketing and the large number of speculative films with titillating titles. The answer from the Cinema Act could be found in $\S 8$. It concluded that all publicly shown films should be subject to censorship according to four moral criteria. The censorship should be carried out by the State Film Control, a public body that was established at the same time..$^{15}$ In this way, the state took control of the presumed power of influence inherent in the moving images.

The other important feature introduced by the Cinema Act was a stipulation that the operation of cinemas required permission from the local authorities. This made it possible for the municipalities to grant a licence to themselves and refuse to accept anyone else. Thus, they were actually given the possibility to establish municipal cinema monopolies, a possibility that they tended to make use of: Between 1913 and 1925 a municipal cinema system evolved in Norway. They organized themselves in a national Municipal Cinematographers' Association (KKL) in 1917 and in The Municipal Film Centre (KF) in 1919. The former was engaged in the showing and viewing of movies, while the latter concentrated on distribution. From the end of the $1920 \mathrm{~s}$, the municipal cinema system controlled approximately $90 \%$ of the total cinema trade in the country - a market share that remained unchanged for the rest of the $20^{\text {th }}$ century. ${ }^{16}$

It was the Liberal Party that fought the hardest for this "municipalization" of the cinemas, in alliance with the Social-Democratic Labour movement. The Conservatives were against this development. This arrangement also met resistance from the film and cinema industry itself: Because the income from the cinemas was transferred to the municipal budgets, this source of revenue could not be used to finance the making of new films. This was the main reason why Norwegian film production turned out to be much smaller than in neighbouring countries. While Sweden and Denmark produced films for the world market, and thus developed a huge film industry, Norwegian films were characterized by difficult working conditions, poor economy and a modest production volume. Norwegian film professionals have been very critical of this situation. ${ }^{17}$

In 1932 an attempt was made to improve this situation when Norwegian Film Ltd. was founded. It was the municipalities themselves who were behind this initiative - later the state also came in among the owners. The company's new studio at Jar just outside of Oslo was ready in 1935. The company's first two independently produced films, To levende og en død and Fant, were released in 1937, inaugurating the "Golden Age" of Norwegian film-making. ${ }^{18}$ In this way, the municipal film and cinema system came to include both production (Norwegian Film Ltd.), distribution (The Municipal Film Centre) and viewing (The Municipal Cinematographers' Association). Norwegian municipalities were thus involved at all three levels in the filmic food chain - an arrangement that no other Western country has ever duplicated. The fundamental structure of the Norwegian film industry was thus developed at a very early stage. This unique municipal film and cinema system later came to be known as "the Norwegian model". ${ }^{19}$

One important condition for the success of this system was the broad audience appeal of the movies. However, this was a characteristic that could also be used for the purposes of propaganda. As had been the case with the press, film could also become part of party politics. In many countries the labour movement quite simply began to 
produce their own workers' movies, inspired by the revolutionary Soviet films that were made by Eisenstein, Pudovkin and others after the Russian Revolution in 1917. The first Norwegian working-class movie was a propaganda film made for the Norwegian Labour Party before the election of 1928 . Up to 1940, approximately 40 working-class films were produced in Norway all in all. They sported inspirational titles like Frem til seier (Forward to Victory, 1930) and Hele folket i arbeid (Work for Everyone, 1933). It was the The Workers' Educational League (AOF) that was the driving force behind these movies. They arranged film viewings with audience numbers that in retrospect seem surprisingly large: In 1932, the AOF arranged 180 viewings with 30,000 spectators, in 1933 there were 255 viewings with 40,000 spectators, in 1934 they showed 685 films for 130,000 people and in 1935 there were 1501 viewings with approximately 290,000 spectators. ${ }^{20}$ In that year (1935), the Labour Party took over the reins of government. With their songs and appeals, the messages in the party movies must have meant a great deal for Labour's election success. The films, after all, reached out to a huge number of voters. Films were also made about Labour newspapers like Kongsvinger Arbeiderblad and Hamar Arbeiderblad. ${ }^{21}$ In this way, working-class movies and party newspapers were united: Both were meant to persuade a mass audience through the party's political propaganda.

\section{NRK: Monopoly on the Airwaves ${ }^{22}$}

Now, we enter the third example of early organizing. Along with the party press and the cinema movies, the masses also got access to the new medium of radio broadcasting. The scale of development here can be seen in terms of the number of radio licences. In the summer of 1924, the first 296 radio licences were registered in Norway. At the end of 1925 , that number had increased to 34,452. In 1930 there were 82,667 radio owners. Then the numbers took off, going from 137,968 licences in 1933 to 429,412 in $1940 .{ }^{23}$ If one counts an average of four listeners per radio set, more than 1.2 million Norwegians had access to the airwaves in 1940. In the autumn of 1941, the radio receivers were confiscated by the German occupational forces. After the war the public had to buy new radios; therefore it took as long as until 1960 before one million licences had been reached. We can still say that radio became the greatest mass medium of its time if we measure the range of every unit of content: The radio transmissions reached huge numbers of listeners simultaneously, even if they were listening individually in their own homes and not as a public crowd at mass meetings. In a strange way the radio contributed to the unification of its listeners, indeed, to the unity of the entire country. The listening masses also supported the broadcasting service economically, as everybody who owned a radio receiver had to pay a licence fee.

The radio involved a revolutionary new technology and had to be organized from scratch. The Norwegian Broadcasting Corporation, popularly known as the NRK, was established in 1933. On the $20^{\text {th }}$ of January that year, the Parliament decided with 91 against 48 votes that the broadcasting service should be organized as a state monopoly. The decision was supported by the Labour Party (40 votes), the Liberals (32) and the Farmers' Party (16), plus a few independents. Those opposed were the Conservatives (36 votes) and a few breakouts from the ranks of the Liberals and the Farmers' Party. The decision was controversial, but a distinct party-political pattern was discernible. The 
state broadcasting system was established by a political alliance between the Centre and the Left of the political spectrum..$^{24}$ Bluntly put: It was the parties of teachers, industrial workers and farmers that supported radio broadcasting as a state-run enterprise.

Then the proposal was sent to the Ministry of Church Affairs, which was now headed by Knut Liestøl, a minister from the new Liberal government. His department now worked out a proposition for a "Broadcasting Act". It contained ready-made arrangements for leadership, organization and the influence of the authorities. The law also introduced the name "Norsk Rikskringkasting". The Parliament passed this law proposal on the $24^{\text {th }}$ of June, 1933, and the law went into effect on the $1^{\text {st }}$ of July the same year. $\S 1$ stated that "the Norwegian Broadcasting Corporation shall have exclusive rights to establish and operate stations and other facilities for the broadcasting of oral messages, music, pictures and similar content". It was the phrase "exclusive rights" that made the NRK a monopoly. That this monopoly should be controlled by the state followed from the January decision. The broadcasting law defined everything that was needed to operate the NRK, including the licence-based financing.

Thus, the NRK was established by the Broadcasting Act - and more than any other individual, it was Knut Liestøl, Minister for Church Affairs in the Liberal government, who was responsible for it. He can thus be regarded as the father of the NRK. The Norwegian Broadcasting Corporation was Norway's answer to the Swedish Radiotjänst, Statsradiofonien in Denmark, Yleisradio in Finland and the BBC in London. The NRK monopoly meant the end of all private radio transmissions that were in operation before 1933.

The NRK was a centralized state monopoly, a centre where the radio broadcasts were transmitted to everyone. The broadcasts disseminated a new microphone-based speech culture, not least in the news bulletins and weather forecasts. Everything soon acquired a relatively official character. The radio transmissions reached so far and wide that the listeners soon began to organize themselves. They established "listener societies", with both a socialist, non-socialist and Christian affiliation. ${ }^{25}$ The Labour listener societies, with 11,000 members, managed to get the Labour movement's spokesmen into many of the programmes. The societies also supported the production of cheap radio receivers, so-called "People's receivers", that had sold approximately 25,000 units by 1940 .

\section{Three Kinds of Control}

Now, consider what we have seen so far: In Norway, newspapers, film and radio evolved into a party press, a municipal cinema system and a state-run broadcasting organization at exactly the same time: the political heyday of the Liberal Party between 1884 and 1935. 1884 was the year when parliamentarianism was introduced in Norway, while 1935 was the year when the Liberals lost their political hegemony to the Labour Party. The Liberals had three outstanding prime ministers during this period. ${ }^{26}$ In different ways, each one of them came to influence the early organization of the media.

Johan Sverdrup (1816-1892) led the fight for the adoption of a parliamentary system in Norway. His efforts were crowned with success in 1884. The Liberal press developed in order to support him in this struggle. Their opponents were conservative parliament representatives, the government administration and King Oscar II living in the Royal Castle in the Swedish capital, Stockholm - and the newspapers that championed their 
cause. It was the emergence of the Liberal press that forced the Conservatives to establish their own newspapers on the Right. After this, it was difficult for new parties to avoid making use of the newspapers to spread their ideas. That is why the Labour movement established their own papers: they had to fight against both the Liberal and the Conservative press. Against this background, we can conclude that it was the intense polarization between the strong Liberal Party led by Johan Sverdrup and the opposition from the Conservatives that was the reason for the emergence of the party press. That struggle was to have a prolonged influence on the Norwegian press.

Then came Prime Minister Gunnar Knudsen (1848-1928). It was his government's Justice Minister, Lars Abrahamsen, who in 1913 introduced the Cinema Act, implementing state-run film censorship and a system of municipal licensing of cinemas. The law established the State Film Control Board and laid the foundations for the municipal cinema system in Norway. ${ }^{27}$ These organizations came to be just as important in their field as the party press was in its own context. Justice Minister Abrahamsen would not have been able to push for such a law without support from his strong-willed boss, Gunnar Knudsen.

In 1933, Johan Ludwig Mowinckel (1870-1943) had just become prime minister in the Liberal Party`s last government when his Minister of Church Affairs, Knut Liestøl, took the initiative to get the Broadcasting Act in place, which established the NRK. Few laws have had such long-range effects as this one has. The law increased the state's administrative and economic control of broadcasting compared to the period before 1933, but the editorial work was actually given a freer hand than before.

Here we clearly see that both the party press, cinema movies and radio broadcasting were shaped in decisive ways during the golden age of the Liberal government between 1884 and 1935, by convictions that can actually be traced back to the party's three most powerful prime ministers. The Liberals were not just the country's first and largest party, but also a grassroots movement based on liberal and radical values. The party still had a strong desire to transform society through control and leadership. This desire was expressed through a combination of centralized reform intentions on the national level and a de-centralized power administered on the local municipal level. The best example of this is the film and cinema act itself: centralized state censorship (the State Film Control) was combined with local control of the cinemas. In this way the strong Norwegian state power, enthusiastically supported by the Liberal press, came to shape the most long-lasting institutions of the film and cinema industry. Ove Solum has pointed out that it was the same forces that established the municipal film and cinema system which also were instrumental in the founding of the NRK: an alliance of politicians from the Liberal Party and politicians from the growing social-democratic Labour movement. ${ }^{28}$ Here we are talking about a Centre-Left alliance with such a formative influence on the organization of the Norwegian mass media that the years from 1884 to 1935 were more decisive than the next fifty were to become.

These decisions had great implications, as the press, film and radio were the only means by which the masses could be reached. Even if they addressed their readers, viewers and listeners in different ways, the three mass media all reached almost the same public. Especially for that reason, it is so interesting that all three, in Norway, had become the subject of outside control. Neither the press, the film industry nor the radio broadcasting were able to develop freely, as they themselves would have wished. 
Instead they were closely linked to powerful actors outside their own field of operations, first and foremost in the Parliament and the state administration. Every party newspaper was expected to toe the party line. The party's politicians could be found both in the municipalities, in the larger counties surrounding them and in the state administration in the capital. The politicians expected loyalty from their own party's newspapers; this was a view shared by the press-workers themselves. The cinema film did not fare any better, as every movie had to pass the censorship of the State Film Control Board. At the same time, operation of the cinemas was dominated by The Municipal Cinematographers Association (KKL) and The Municipal Film Centre (KF). After the establishment of Norwegian Film Ltd. in 1932, the politicians, at least indirectly, actually took control of both production, distribution and viewing. A particularly important role was played by prominent local politicians like Kristoffer Aamot (Labour), Rolf Hofmo (Labour), Rolf Stranger (Conservatives) and a number of other municipal politicians. Together they controlled Norwegian Film Ltd. until the mid-1960s. ${ }^{29}$ It took until 1964 for the country's film workers to rebel against political control over the Norwegian film production. ${ }^{30}$ State control was even more noticeable with regard to the NRK, which was indeed a state institution with a legal monopoly on broadcasting. The NRK was subject to the will of the Parliament and its government authorities: broadcasting was the responsibility of the Ministry of Education and Church Affairs, but it was the Parliament that passed the budget proposals. The assembly also conducted annual debates about the programming operations of the NRK. The appointment of director general of the NRK was made by the government, while the members of the Broadcasting Council were appointed by the government and the Parliament.

In this way, Norwegian mass media came to function as an extension of the country's political system. The foundations for such a development were made during the heyday of the Liberal Party between 1884 and 1935, but the structures were prolonged and developed further during the Labour Party's long period in power from 1935 to 1965. The result was that the mass media developed so many and such close ties to politicians and parties that it is difficult to draw any demarcation lines between them. The patterns made primarily by the Centre-Left alliance also had significance in the case of television.

\section{Television: The Greatest Mass Medium}

Norwegian television had a great mass-audience appeal. This is shown by the number of TV licences. When the NRK's television division officially started up on the $20^{\text {th }}$ of August 1960, 16,876 Norwegians had already paid their licence fee. Before the year was up, the number had increased to 48,572 . The next few years saw a further increase: In 1961, the number of licences hit 107,000, in 1962 204,000, in 1963292,000 and in 1964 406,000. In 1970, 850,000 Norwegians had paid their TV licence fee, and in 1974 the number exceeded one million. In the course of a little more than ten years, then, just about the entire Norwegian population had bought their own television set. This growth was more rapid than had been the case for any earlier medium in the country. After 1970 one might justifiably say that the television audience was synonymous with the whole nation. The masses had become a crowd.

Television was the biggest of all the mass media: no other medium had penetrated the Norwegian society and population so thoroughly and so extensively. This fact had a 
number of consequences. The entire country watched the TV transmissions: Two minutes on the television screen was enough to make a person or an event well-known from one end of the country to the other. The impact of the medium was enormous; television commanded the viewers' attention in a unique way. Programmes like the news, children's television, the Monday night movie, the Detective Hour and the Saturday entertainment shows became important events in the life of the country.

From the very beginning, television became a matter for the NRK. This followed from the Broadcasting Act of 1933, where $\S 1$ had laid down that the NRK also had a "monopoly" on the transmission of "pictures and the like." The law thus banned anyone but the NRK from engaging in radio and television in Norway. Therefore, Norwegian television also became a matter for the NRK monopoly. The country only acquired one TV channel. Until 1980, Norwegian television can actually be seen as a realization of what was contained in the term "pictures" in Knut Liestøls Broadcasting Act of 1933.

For the public, television had revolutionary effects. Suddenly the whole world entered Norwegian living rooms, with living pictures and synchronous sound. People experienced the assassination of US President John F. Kennedy in 1963, the protracted Vietnam War, the heartbreaking famine in Biafra and the amazing moon landings of the Apollo space programme, giving rise to any number of strong impressions. It is therefore easy to maintain that television brought with it a new culture of the image, but that would be to simplify things unduly. Such an assertion presupposes, in fact, that the media in the period prior to the advent of television were not concerned about visuals, and that is not really true. On the contrary, in the 1950s almost all of the mass media started using visual effects: the newspapers used press photos, the weekly magazines used coloured prints and large picture surfaces. At the same time, cartoons and comic strips enjoyed a breakthrough, starting in 1948, led by the hugely successful Donald Duck \& Co, movies at the cinema, which were now shown in widescreen colour, even in 3D. Even radio tried to become visual: the programme makers formed sound pictures - in radio plays and during the Children's Hour, for instance - and tried to appeal to listeners' picture-making imagination. It would therefore be true to say that television, from 1960 onwards, entered an imagistic culture that had already been created by the other media.

Throughout the 1960s and 1970s, NRK television became a dominant power in Norwegian society. The other mass media simply had to adjust and adapt. The press began printing TV-related material and went in for a more popular type of journalism. In this field, the newspaper Verdens Gang ( $V G$ for short) was particularly innovative. These changes had the effect of making the traditional party press seem old-fashioned and outdated - and after 1972 it started to fade away. The weekly magazines adapted fairly quickly and came back strongly in the 1970s. Hjemmet led the field, closely followed by Norsk Ukeblad and Allers. In 1978, a new weekly magazine called Se og Hør started up and quickly became the leading celebrity magazine in the country. While the TV audience just kept on growing, the cinema attendance was cut in half. The radio programmers changed their tune to allow for easily accessible and varied programmes like Nitimen and Politisk kvarter. ${ }^{31}$

In this way, television forced the other media to become more audience friendly. These adaptive strategies were mostly carried out before 1980. Along the way, the state intervened with public subsidies: a purchasing system for imaginative literature, production support for films and press subsidies for the newspapers. Keeping the media in 
good shape was becoming a state responsibility and a part of the nation's culture politics. The press subsidies, which were inaugurated in 1969, were the most far-reaching measure. ${ }^{32}$ Despite all these new initiatives, we may still conclude that NRK Television only changed to a limited extent the fundamental media patterns that the Broadcasting Act had established in 1933. Until 1980, NRK-TV can be regarded as an aftereffect of this law.

\section{Changing Control (1980-2000)}

All this shows not only how important the early organization of the Norwegian media became in the early part of the $20^{\text {th }}$ century, but also that the established patterns lasted for a long time. In fact, we find no fundamental changes until we get to the 1980s and1990s. During these decades, the Norwegian mass media entered a new era characterized by a great deal of changes and adjustments. The force shaping these changes was a combination of political liberalization and new technology. The liberalization of policy - led by the new conservative government of prime minister Kåre Willoch from 1981 - was in fact a Norwegian parallel to the new liberalism of Margaret Thatcher in Britain and Ronald Reagan in the US. The liberalization ended state monopolies and enabled a freer movement of capital, which had important consequences for the press, film, radio and television. In fact, this was the first challenge to the long-lasting power of the political Centre-Left alliance to shape the media organization early in the $20^{\text {th }}$ century.

The party press, which had existed for a hundred years, started to disintegrate. The ties that had bound the newspapers to the political parties had grown gradually weaker. The first signs of this could be observed already towards the end of the 1960s, but this development increased in speed especially after the intense debate on Norway's potential membership in the European Community in 1972. The victory for the nay-sayers led to a split of the Liberal Party into two separate parties. The Liberal press was divided in the same way, but shortly afterwards both newspaper groups broke with their respective parties. Thus the Liberal press became the first party-political newspaper group to disappear. In the 1980s, the Conservative and the Agrarian press followed suit. Early in the 1990s the time had come for the mighty Labour press, as this press group broke its formal ties to the Labour Party in 1991 by changing its intentions clause. The fall of the Norwegian party press became a protracted and often conflict-filled process of liberation that dragged on for four decades. In the 1990s, the newspapers proclaimed their new independence from party affiliations. The party-political newspaper organizations disappeared, while the political press offices were closed down or changed their names. The number of party newspapers dwindled, and papers with political titles changed their names: Bergens Arbeiderblad became Bergensavisen (BA), Arbeiderbladet continued as Dagsavisen, etc. Every word with political connotations was removed from the titles. While the party press was disintegrating, the popular tabloid $V G$ had become Norway's largest newspaper in terms of circulation.

These important changes also had considerable impact on the newspapers' corporate arrangements. Most of them went from being family firms and cooperative societies to becoming limited liability companies, subject to the stipulations of the Companies Act that required a board of directors, a general shareholders' meeting, and so on. This meant that they also became interesting for private investors. Because economic liberalization policies were so dominant at the time, newspapers were now increasingly attractive to 
media companies as objects of investments. The company Orkla led the way by buying up Moss Avis in 1985. This was the start of a long-term purchasing strategy, which provided the foundations for Orkla Media as a concern. The growth of Orkla Media challenged the old family-run business of Schibsted, which owned Aftenposten and $V G$, to develop into a similar media group. In 1990-91, the Labour press also changed to the corporate model and changed its name to A-Pressen. In the course of just a few years, three large media concerns had taken over a field that had been dominated by the party press since the $1880 \mathrm{~s}^{33}$

Such changes and adjustments also hit the film and cinema business. Private capital surfaced here too, in the form of limited partnerships. They now aimed to finance new films and achieved great success with the thriller Orions Belte, set in Spitzbergen in 1985. Such limited partnerships also financed a large number of other films. ${ }^{34}$ The state production company Norwegian Film Ltd. made popular films like The Pathfinder (1987) and Insomnia (1997) etc., actually leading to a whole string of successful films. Even so, the state authorities decided not to keep the production company, and in 2001 Norwegian Film Ltd. was closed down. Instead the state decided to subsidize Norwegian film production directly. Film censorship for adults became more liberal, while the age limits for children and adolescents were retained. After a while, the censorship evaluations were transferred to The Media Supervision Authority. ${ }^{35}$ The municipal cinema system also came under pressure from private capital. However, the Municipal Cinematographers' National Association changed its name to Film and Cinema in 2002 and managed to keep its position. Adherents to the municipal cinema system argued that the traditional set-up constituted a public service institution. ${ }^{36}$

For the press, film and cinema, these changes and adjustments took place over a relatively long time. For the NRK, however, the changes came quite abruptly. On the $16^{\text {th }}$ of December 1981, the Culture Minister of the new Conservative government, Lars Roar Langslet, awarded a number of licences to local radio and television stations that were independent of the NRK. With that, the NRK's "sole right" established in 1933 was history. The broadcasting monopoly was abolished. Technological developments pointed in the same direction: Video games had already made their entrance into Norwegian homes, while TV transmissions via satellite were growing in number, being received through the satellite dishes spreading across the country. Because of the new technology, maintaining the NRK monopoly had become increasingly difficult, but many people also perceived the state monopoly to be problematic in an increasingly pluralistic society. Lars Roar Langslet therefore allowed the transmission rights of the NRK to be divided up and distributed among new actors. As a result, organizations, congregations, building cooperatives and local communities could now involve themselves in radio and TV transmissions.

Thus, a new private radio and television industry emerged. A new commercial channel transmitting from London, TV3, arrived in 1987, closely followed by another newcomer, TV-Norge, in 1988. These television channels siphoned off advertising money from Norwegian businesses and sent it out of the country. That settled it for the politicians. In 1990 the Parliament decided to start up a private TV 2, to be financed with advertising money. The establishment of TV 2 was also justified by the need to create an alternative to the NRK. The licence for TV 2 was advertised and awarded in 1991. On the $5^{\text {th }}$ of September 1992, everything was ready for TV 2 to start its own programming. 
The new TV channel was a commercial venture and challenged the NRK with a fresh and aggressive style. The NRK had to fight to keep its position, and so it had to begin competing for viewers. A similar development took place in the field of radio. The new local radio stations also challenged the NRK, which responded by instituting a new three-channel system in 1993: P1, P2 and P3 each with their own unique profile, while the private $\mathrm{P} 4$ became radio's parallel to TV 2. The new channels launched unfamiliar programme concepts and created their own celebrities. The NRK, at the same time, managed to adjust its profiles in a surprisingly innovative way, especially during the period 1989-2001, when Einar Førde - a former politician from the Labour party - was director general of the NRK. ${ }^{37}$

In this way, during the period 1980-2000, change came to characterize everything from the press and film to radio and television or in short: all the four major mass media. Up until 1980 they had each constituted their own sector. In reality, they had had very little to do with each other in terms of formal organization. What was new about the changes that took place between 1980 and 2000 was the way they ended many of the ties that had connected the mass media to the political system ever since their breakthrough. The cumulative effect of media-political liberalization, new technology and private capital now led to the creation of new cross-connections between the various media quite contrary to earlier dividing lines. For the first time, the media as a whole became its own distinct area: a detached and independent media sector. ${ }^{38}$ All this occurred as the culmination of many isolated decisions taken by many different people in business and politics, and not as a consequence of one big and overreaching plan. ${ }^{39}$ But, taken together, the different decisions all led in the same direction: towards liberalization of the former tightly organized media. Today, it has become common to view this sector as a media industry. This industry functions on ordinary business terms: The activities are meant to generate a profit for shareholders and investors. Therefore, the economic results - the bottom line - have become more and more important. ${ }^{40}$

\section{Conclusion}

Now, we can return to the question that was raised at the beginning of the article: How important was the organizing of mass communications in Norway in the early part of the 20th century? The discussion above has shown that the newspaper press, the film and cinema business and radio broadcasting were formed in decisive ways at exactly the same time; the period when the Liberal Party dominated the government between 1884 and 1935. In fact, these years became formative for all three kinds of media. Looking at the details, we see that the media were shaped to a high degree by the power of the Centre-Left alliance in the Parliament. The Liberal policy was of course supported by the Liberal party press, but also by the Labour press when it came to topics like film regulation (The Cinema Act of 1913) and the municipality system of cinema theatres, but also regarding the formation of the NRK as a state-run broadcaster with a national monopoly of the airwaves (The Broadcasting Act of 1933). The Broadcasting Act was also supported by the Agrarian party. The sum of all this was the establishment of a specific Norwegian way of organizing mass communications, what we may call the Norwegian media system. What characterized this system was that the media more than anything all became an extension of the political system; voter-generated power played an active 
part in the organization of both the press, film/cinema and radio broadcasting. And it was in particular the political parties on the Centre and Left of the political spectrum that used their power to shape the media system of the nation. Many politicians were active with regard to all the different media.

After the system was formed, it dominated Norway for the rest of the $20^{\text {th }}$ century: continuity and stability reigned during the years of the Labour government from 1935 to 1965 , and the main traits also lasted through the 1970 s - until all the transformations began in the 1980s and 1990s. The pattern of early importance also influenced the development of television, placing the NRK in a dominant position right from the early days of TV in the 1950s.

Thus, we have confirmed the importance of the early years of mass communications and the organizing of them, also in a small country like Norway. Our case study confirms the major findings from American scholars like Robert McChesney and his British colleagues, working with the same time period: In fact, it is impossible to understand the later media development without a detailed investigation of the early years, an era when mighty men used their power to influence the organizing of mass communications and thus formed the media of the whole nation - with consequences that persisted throughout the $20^{\text {th }}$ century and into the $21^{\text {st }}$. Consequently, we can say that the importance of the early years is not a pattern that we only find in big countries like the United States and Great Britain; we find the same pattern in the case of Norway, although there the social forces were different. In Norway, it was the Centre-Left Alliance in the Parliament that was most powerful, not private business corporations as in the US and the UK. This alliance created what we may call a social-democratic media system.

This finding is interesting, but we still do not know whether we will find the same pattern of early importance in other small countries. We need more studies of the development of the media system in such countries, especially outside the Anglo-American world. These studies should be comparative in their approach. The Norwegian media system, for instance, can be compared to those of the neighbouring countries Sweden and Denmark. Both countries developed a party press and also a broadcasting monopoly run by the state, but neither of them developed a film and cinema model as in Norway. In fact, Sweden and Denmark very early on developed a private film industry - impressing the world with names like Victor Sjöström, Mauritz Stiller, Greta Garbo, Ingrid Bergman, Ingmar Bergman, Asta Nielsen and Carl Th. Dreyer. They had grown out of a strong film industry, with production companies like Svensk Filmindustri (established 1919) and Nordisk Film (established 1906). These start-up years indicate that the early period of mass communications also was of great importance in Sweden and Denmark - and thus seem to confirm the importance of the early years, but because these firms were private enterprises we do not encounter the Norwegian pattern, where all the mass media became an extension of the political system - based on voter-generated power. So, even if the Swedish and Danish media have many similarities with the Norwegian media - especially the great importance of the early formation of press and broadcasting - the Norwegian media system shows some peculiarities that we do not find in the neighbouring countries: the power of the Centre-Left Alliance in the Parliament and how it formed the mass media.

This opens the door to a much wider discussion of similarities and differences between the media in Norway, Sweden and Denmark than we can include in the present 
article. In fact, we need a better understanding of the media models in each of the Nordic countries. Such a discussion could use as its starting point the way that Hallin and Mancini define the media system in the central and northern part of Europe as "the democratic-corporatist model." ${ }^{41}$ This concept - and their way of analysing it - was new when they published their book in 2004, but after ten years of scholarly discussion of it, it is my opinion that we need to develop the analysis of national media systems and their differences in each of the Nordic countries a great deal further - from the beginning of the modern media up to the present.

\section{Epilogue: Towards a Nordic Media Model?}

Today, there are many indications that the era of national peculiarities in the media sector is over. It seems that the differences between the Nordic countries are getting smaller while the similarities between them are increasing. Some of the most recent changes for the Norwegian media show this: in 2012, the Norwegian television channel TV 2 was bought by the Danish Egmont corporation, and in 2013, the Norwegian newspaper Dagbladet was taken over by the Danish Aller group. And on April $4^{\text {th }} 2013$, the old cinema structure in Oslo - owned by the municipality - was sold to the Danish Egmont/Nordisk Film. This means that very important Norwegian media no longer have national ownership. On the other hand, the Norwegian media group Schibsted also owns important newspapers in the neighbouring countries, like Aftonbladet and Svenska Dagbladet in Sweden, etc.

This media activity, crossing the national borders in Scandinavia, has increased to such a degree that it is becoming more and more difficult to define and limit media systems in terms of a single nation - as we have done until now. The media development in Norway, Sweden and Denmark is changing from national solutions and models to activities on a Nordic level, covering the whole of Scandinavia. Just consider the popular talk show Skavlan - from 2013 shown on television both in Norway (NRK), Sweden (SVT) and Denmark (DR). Such examples indicate that we need to develop common characterizations on a Nordic level if we wish to analyse more than one country in the region. What we need now are comparative studies of the media development in the Nordic countries. ${ }^{42}$ Nordic scholars should develop their work much further than Hallin and Mancini did when they wrote about Scandinavia. It is a weakness in their book that their concept of the "democratic-corporatist media model" includes very different countries both in the central and northern part of Europe. Because of this, their analysis of the Nordic countries is very general, not focused on national peculiarities like the Centre-Left Alliance in Norway and how they used their power in the early part of the $20^{\text {th }}$ century to influence the long-term media development in the country. It will be an interesting task for Nordic scholars to discuss further both the similarities and differences between Norway, Sweden and Denmark on this issue - and to show to what degree these countries today have moved towards what may be called a Nordic media model. Whether this is a fruitful concept - and to what degree it requires a historical and/or a contemporary approach - is a topic for future research. ${ }^{43}$ 


\section{Notes}

1. Douglas 1987, McChesney 1994, Winston 1998, Emery, Emery and Roberts 2000, Gabler 2006

2. Barnouw 1990, Briggs 1995, Briggs and Burke 2002

3. This paragraph is based on the Introduction and Chapter 1 and 2 in Bastiansen and Dahl 2008: 11-151. See also Jørgensen 1970 and Seip 1988.

4. Eisenstein 1983, see also Briggs and Burke 2002.

5. See Bliksrud 1999

6. This paragraph is based on Chapter 3 in Bastiansen and Dahl 2008: 153-234. See also Høyer 1995 and Eide (ed.) 2010

7. Here we use Oslo as the name of the Norwegian capital, even if its previous name was Christiania or Kristiania.

8. Bastiansen and Dahl 2008: 220-226

9. Quoted from Bastiansen and Dahl 2008: 226

10. See the annual reports of the Norwegian Labour Party from 1920 onwards.

11. Quoted according to Reklamens Reklame No.12, September 1938. This was the Conservative press' internal magazine for advertisers from the business world.

12. See my own contributions about the party press in Volumes 2 and 3 of The History of the Norwegian Press 1660-2010 and Bastiansen 2009. See also Høyer 1995, Ottosen, Østbye and Røssland 2011, Overrein 2001.

13. Disen 1997: 274

14. Iversen 2011, Evensmo 1967, Nistad 1992

15. Meland and Igdun 2001, Pedersen Nymo 2003

16. Asbjørnsen and Solum 1998, 2000 and 2008, Solum 2004, Evensmo 1967

17. Sinding 1972, Solum 2004

18. Nistad 1992

19. Asbjørnsen and Solum 2008

20. Sørenssen 1980: 324-325

21. Sørenssen 1980: 351 and following

22. This paragraph is based on Dahl 1975, Bastiansen and Dahl 2008, Chapter 4, and Halse and Østbye 2001

23. Dahl 1975: 369

24. Dahl 1975: 211, Dahl and Bastiansen 2000: 80 following, Halse and Østbye 2001

25. Brohaug 1974, see also Dahl 1975: 340 and following

26. See Forr, Hegge and Njølstad 2010

27. See Solum 2004, Evensmo 1967

28. Solum 2004: 326-336, see also Dahl 1975: 211

29. See articles about Kristoffer Aamot, Rolf Stranger and Rolf Hofmo in Norsk Biografisk Leksikon (Norwegian Biographical Encyclopaedia)

30. Thoresen 1996, see also Evensmo 1967: 333 and following

31. See Gunnar Gran 2000, and Dahl and Bastiansen 1999, Chapter 6

32. This section is based on Chapters 5 and 6 in Bastiansen and Dahl 2008. For press subsidies see Høst 2009: 67 and the following pages.

33. Bastiansen 2006, Bastiansen 2009, Johansen 2011, Roppen 2003, Norland 2011

34. Nistad 1992: 94

35. Nistad 1992, Smith-Isaksen 2004, Holst 2006: 145 and following, Iversen and Solum 2010, Iversen 2011, Pedersen Nymo 2003 and 2006

36. Solum and Asbjørnsen 1998, 2000, 2008

37. Halse and Østbye 2001

38. The underlying processes of this development have been analysed theoretically in Luhman 2002. See also Rasmussen 2003

39. See, for instance, how TV Norge was established as a private and commercial TV channel outside the NRK by four friends; Rynning 1996

40. Roppen 2004

41. Hallin and Mancini 2004: $143 \mathrm{ff}$

42. See Chapman 2005 as example of the comparative approach in media history

43. For a common Scandinavian perspective on media like broadcasting, see Carlsson (ed.) 2013, and Anker Brink Lund, Lars Nord and Johann Roppen 2009. For studies of television in Scandinavia, see Bono and Bondebjerg (eds.) 1996, and for studies of television in smaller countries, see Lowe and Nissen (eds.) 2011 


\section{Sources}

Annual reports for The Norwegian Labour Party 1920-1930

Reklamens reklame, nr. 12, september 1938

Film og Kino, annual reports

Articles about Kristoffer Aamot, Rolf Stranger and Rolf Hofmo in Norsk Biografisk Leksikon (Norwegian Biographical Encyclopedia, Kunnskapsforlaget, Oslo

\section{References}

Asbjørnsen, D. and O. Solum (1998) "Public service-kino?, Legitimeringsstrategier i norsk kinopolitikk", in Norsk Medietidsskrift nr. 1.

Asbjørnsen, D. and O. Solum (2000) Det norske kommunale kinosystemet: legitimeringsstrategier og filmrepertoar, IMKs skriftserie nr. 39, Institutt for medier og kommunikasjon, Universitety of Oslo.

Asbjørnsen, D. and O. Solum (eds.) (2008) Film og kino. Den norske modellen, Unipub forlag.

Barnouw, E. (1990) Tube of Plenty, The Evolution of American Television, Oxford University Press,

Bastiansen, H.G. (2006) Da avisene møtte TV. Partipressen, politikken og fjernsynet 1960-1972, doktoral dissertation for the Dr.art. title at Facultety of Arts and Humanities, University of Oslo.

Bastiansen, H.G. (2009) Lojaliteten som brast. Partipressen i Norge fra senit til fall 1945-2000, Pressehistoriske skrifter no. 11, Norsk Pressehistorisk Forening.

Bastiansen, H.G. (2009) Partipressen konsolideres 1920-1940, manuscript to volume 2 of Norsk Presses Historie, Oslo.

Bastiansen, H.G. and H.F. Dahl (2008) Norsk mediehistorie, 2. utg., Universitetsforlaget, Oslo.

Bliksrud, L. (1999) Den smilende makten. Norske Selskab i København og Johan Herman Wessel, Aschehoug, Oslo.

Bono, F. and I. Bondebjerg (eds.) (1996) Television in Scandinavia. History, Politics and Aesthetics, Acamedia Research Monograph 20, Luton University Press.

Briggs, A. (1995) The Birth of Broadcasting 1896-1927, The History of Broadcasting in the United Kingdom, Volume 1, Oxford University Press, Second Edition.

Briggs, A. and P. Burke (2002) A Social History of the Media. From Gutenberg to the Internet, Polity Press, Cambridge.

Brohaug, T.-E. (1974) Kringkastingen og lytterne. Lytterbevegelsene 1925-1940, hovedoppgave i historie, Universitetet i Oslo.

Carlsson, U. (ed.) (2013) Public Service Media from a Nordic Horizon. Politics, Markets, Programming and Users, Nordic Public Service Media Map 2, Nordicom, Göteborgs Universitet.

Chapman, J. (2005) Comparative Media History. An Introduction : 1789 to the Present, Polity Press, Cambridge.

Dahl, H.F. (1975) Hallo-hallo! Kringkastingen i Norge 1920-1940, Cappelen, Oslo.

Dahl, H.F. (1978) Dette er London, NRK i krig 1940-1945, Cappelen, Oslo.

Dahl, H.F. and H.G. Bastiansen (2000) Hvor fritt et land. Sensur og meningstvang i Norge i det 20. århundre, Cappelen, Oslo.

Disen, O. H.P. (1997) Den store illusjonen. Filmbyråenes historie, Norske Filmbyråers Forening, Oslo.

Douglas, S.J. (1987) Inventing American Broadcasting 1899-1922, Johns Hopkins University Press, Baltimore.

Eide, M. (red.) (2010) En samfunnsmakt blir til 1660-1880, Volume I of Norsk presses historie 1660-2010, Universitetsforlaget, Oslo.

Eisenstein, E. (1983) The Printing Revolution in Early Modern Europe, Cambridge University Press.

Emery, E. and N. Roberts (2000) The Press and America, An Interpretative History of the Mass Media, Allyn and Bacon, Boston, Ninth Edition.

Evensmo, S. (1967) Det store tivoli. Film og kino i Norge gjennom 70 år, Gyldendal Norsk Forlag, Oslo.

Forr, G., P.E. Hegge and O. Njølstad (2010) Mellom plikt og lyst. Norske statsministre 1873-2010, Dinamo Forlag, Oslo.

Gabler, N. (2006) Walt Disney. The Triumph of the American Imagination, Vintage Books, New York

Gasset, J. Ortega y (1934)Massenes oprør, Gyldendal Norsk Forlag, Oslo.

Gran, G. (2000) Men radioen var ikke død. NRK i oppbruddstiden på 60- og 70-tallet - sett fra innsiden, NRK, Oslo.

Hallin, D.C. and P. Mancini (2004) Comparing Media Systems. Three Models of Media and Politics, Cambridge University Press, Cambridge.

Halse, K.J. and H. Østbye (2001) Norsk kringkastingshistorie, Samlaget, Oslo.

Hannemyr, Gisle (2005) Hva er internett, Universitetsforlaget, Oslo.

Hjeltnes, G. (ed.) (2010) Imperiet vakler 1945-2010, Volume 3 of Norsk Presses Historie 1660-2010, Universitetsforlaget, Oslo. 
Høst, S. (2009) Mye mer enn Akersgata. Norsk pressestruktur 1945-2009, Pressehistoriske Skrifter nr. 12, Norsk Pressehistorisk Forening, Oslo.

Høyer, S. (1995) Pressen mellom teknologi og samfunn. Norske og internasjonale perspektiver på pressehistorien fra Gutenberg til vår tid, Universitetsforlaget, Oslo.

Holst, J.E. (2006) Det lille sirkus. Et essay om norske filmer og produksjonsforhold 1946-2006, Norsk Filminstitutt, Oslo.

Iversen, G. (2011) Norsk Filmhistorie, Universitetsforlaget, Oslo.

Iversen, G. and O. Solum (2010) Den norske filmbølgen. Fra Orions belte til Max Manus, Universitetsforlaget, Oslo.

Johansen, T.A. (2011) Orkla Media 1983-2006. Et medieselskap i konserndanningens og eierkonsentrasjonens epoke, Norsk Pressehistorisk Forening/Edda Media, Oslo.

Jørgensen, H. (1970) Da censuren ble opgivet, Det Berlingske bogtrykkeri, København.

Luhman, N. (2002) Massemediernes realitet, Hans Reitzels forlag, København .

Lund, A. Brink, L. Nord and J. Roppen (2009) Nye udfordringer for gamle medier. Skandinavisk public service $i$ det 21. Arhundrede, Nordicom, Göteborgs Universitet.

Lowe, G. Ferell and C.S. Nissen (eds.) (2011) Small Among Giants. Television Broadcasting in Smaller Countries, Nordicom: University of Gothenburg.

McChesney, R.(1994) Telecommnications, Mass Media and Democracy. The Battle for the Control of U.S. Broadcasting 1928-1935, Oxford University Press, New York and London.

Meland, Ø. and S. Igdun (2001) “"Fiendtlig mot fremmed makt”, Statens Filmkontroll og den politiske filmsensur 1913-1920", in Henrik G. Bastiansen og Øystein Meland (eds.): Fra Eidsvoll til Marienlyst. Studier i norske mediers historie fra Grunnloven til TV-alderen, Høyskoleforlaget, Kristiansand.

Nistad, E. (1992) Klart for opptak. Glimt fra 60 års filmhistorie-Norsk Film AS 1932- 1992, A-trykk, Vennesla.

Norland, A. (2011) Bly blir gull. Schibsteds historie 1839-1933, Schibsted forlag, Oslo.

Nymo, T. Pedersen (2003) Slibrige scener - listige knep. Statens Filmkontroll og den moralske orden 19131940, Scandinavian Academic Press/Spartacus Forlag, Oslo.

Nymo, T. Pedersen (2006) Under forvandlingens lov. Norsk Filminstitutts historie, Norsk Filminstitutt, Oslo.

Ottosen, R. (ed.) (2010) Presse, parti og publikum 1880-1945, volume II of Norsk Presses Historie 16602010, Universitetsforlaget, Oslo.

Ottosen, R., H. Østbye and Lars Arve Røssland (2011) Norsk pressehistorie, Samlaget, 2. utgave, Oslo.

Overrein, P. (2001) "Hvor ånden bcerer bud", Østlendingen fra Arbeiderdemokratene til Orkla, Østlendingen, Elverum.

Rasmussen, T. (2003) Luhmann. Kommunikasjon, medier, samfunn, Fagbokforlaget, Bergen.

Roppen, J. (2003) Orklas lange revolusjon. Konsern, redaktørar og journalistikk i Orkla Medias norske aviser 1985-2000, Publikasjon nr. 56, Institutt for medievitenskap, Universitetet i Bergen.

Roppen, J. (2004) Medieindustrien. Innføring i medieøkonomi, Det norske Samlaget, Oslo.

Rynning, E. (1996) TV-revolusjonen i NRK. Maktspill og intriger, MLI International Consultans AS, Oslo.

Seip, J. Arup (1988) 'Teorien om det opinionsstyrte enevelde", in Politisk ideologi. Tre laerestykker, Universitetsforlaget, Oslo.

Sinding, L. (1972) En filmsaga, Fra norsk filmkunsts begynnelse. Stumfilmårene som jeg så og opplevet dem, Universitetsforlaget, Oslo.

Smith-Isaksen, M. (2004) Alle gode krefter må samles, Om norske myndigheters håndtering av videovold, hovedoppgave i medievitenskap, Universitetet i Oslo.

Solum, O. (2004) Helt og skurk. Om den kommunale film-og kinoinstitusjonens etablering i Norge, doctoral dissertation, University of Oslo.

Sørenssen, B. (1980) "Gryr i Norden”, Norsk arbeiderfilm 1928-1940 i internasjonalt perspektiv, doctoral dissertation, University of Trondheim.

Thoresen, T. Breda (1996) Gjester i studio. Historien om "de 44" og opprøret mot Norsk Film AS, Aventura, Oslo.

Winston, B. (1998) Media Technology and Society: A History: From the Telegraph to the Internet.

Østbye, H. (1972) Om innføring av fjernsyn i Norge, hovedoppgave, NAVFs sekretariat for mediaforskning, Sosiologisk institutt, Universitetet i Bergen.

Østbye, H. (1988) Mediepolitikk. Skal medieutviklingen styres?, Universitetsforlaget, Oslo.

HENRIK G. BASTIANSEN, Dr. art., Associate Professor, Faculty of Media and Journalism, Volda University College, henrik.bastiansen@hivolda.no 